\title{
Antarctic fur seals foraging in the Polar Frontal Zone: inter-annual shifts in diet as shown from fecal and fatty acid analyses
}

\author{
Mary-Anne Lea ${ }^{1,2, *}$, Yves Cherel ${ }^{2}$, Christophe Guinet ${ }^{2}$, Peter D. Nichols ${ }^{3,4}$ \\ ${ }^{1}$ Antarctic Wildlife Research Unit, School of Zoology, University of Tasmania, PO Box 252-05, Hobart, Tasmania 7001, Australia \\ ${ }^{2}$ Centre d'Etudes Biologiques de Chizé-CNRS, 79360 Beauvoir-sur-Niort, France \\ ${ }^{3}$ Commonwealth Scientific \& Industrial Research Organisation (CSIRO) Marine Research, Castray Explanade, Hobart, \\ Tasmania 7001, Australia \\ ${ }^{4}$ Antarctic Commonwealth Research Centre, University of Tasmania, PO Box 252-80, Hobart, Tasmania 7001, Australia
}

\begin{abstract}
We studied the dietary preferences of Antarctic fur seals Arctocephalus gazella from Cap Noir, Îles Kerguelen, foraging in the Antarctic Polar Frontal Zone (PFZ) in February of 1998, 1999 and 2000. Scats were collected and analyzed for remaining prey hard parts in each of the 3 years, and in 1999 and 2000, the fatty acid (FA) composition of fur seal milk samples was also examined for longerterm dietary preferences. Scat analyses revealed that seals foraged primarily on fish and some squid in all 3 years with 25 species of fish being taken during the study. Myctophid fish accounted for an average of $94 \%$ by number of all fish consumed with 3 species, Gymnoscopelus nicholsi, G. piabilis and Electrona subaspera, forming the core diet. Inter-annual differences in dietary species composition were apparent, however, with the presence of the mackerel icefish Champsocephalus gunnari in 1998 and the myctophid Protomyctophum tenisoni in 1999 accounting primarily for the differences observed between years. While reconstituted prey biomass per scat was similar between years, scats from 1998 represented less energy per gram than those from 1999 and 2000. This study highlights the usefulness of using FA signature analysis to confirm longer-term shifts in dietary intake of fur seals using milk samples. Polyunsaturated fatty acids (PUFAs) were significantly more prevalent in the 1999 milk samples, which were also lower in overall lipid content (43\% vs $53 \%$ ). G. nicholsi, a particularly oily fish, occurred in higher proportions in the diet in 2000, perhaps explaining the higher incidence of monounsaturated fatty acids (MUFAs) in this year and the generally higher lipid levels present in milk samples. The inter-annual variation in the diet of Antarctic fur seals confirmed by these 2 techniques lends support to the hypothesis that previously identified variations in oceanographic conditions surrounding Îles Kerguelen in 1998, 1999 and 2000 affect the availability of fur seal prey resources.
\end{abstract}

KEY WORDS: Myctophid · Fatty acid $\cdot$ Kerguelen $\cdot$ Lipids $\cdot$ Fish $\cdot$ Squid $\cdot$ Arctocephalus gazella

\section{INTRODUCTION}

The Southern Ocean ecosystem is strongly influenced by the movement of several strong currents, most notably the Antarctic circumpolar current, and coupled climatic anomalies such as the Antarctic circumpolar wave (White \& Peterson 1996). While primary production is relatively low in open parts of the Southern Ocean (Hempel 1985), frontal regions may form

*Email: ma_lea@utas.edu.au discrete areas of biological enhancement (Lutjeharms et al. 1985). Studies of zooplankton communities in the vicinity of the Antarctic Polar Frontal Zone (PFZ) have identified regions of high productivity that vary at a range of spatial and temporal scales (Pakhomov et al. 1994, Pakhomov \& Froneman 2000, Hunt et al. 2001). Consequently, the ecosystem also supports a very high biomass of vertebrate predators such as otariid seals, penguins and seabirds, which are limited in their distribution by their ability to travel from breeding sites while provisioning their offspring. Antarctic fur seals 
raise a single pup over a 4 mo lactation period from December to March during which they spend time foraging at sea followed by periods ashore suckling their pup (Doidge et al. 1986). As central place foragers, they are limited in their prospecting range by the fasting constraints of their young; consequently, oceanographic variation within their foraging range could affect the species composition of prey available to them.

The Antarctic krill Euphausia superba comprises a large part of the zooplankton biomass in the Southern Ocean (Schnack 1985), providing a food source for a large proportion of marine predators south of the Antarctic Polar Front (PF), particularly in the vicinity of the Scotia Sea (Croxall et al. 1985, Reid 1995, Reid \& Arnould 1996). Many sub-Antarctic predators however, such as king penguins, Antarctic fur seals, large pelagic fish and several species of squid (Sabourenkov 1991, Cherel \& Ridoux 1992, Rodhouse \& White 1995, Bost et al. 1997, Cherel et al. 1997, Goldsworthy et al. 1997, Green et al. 1997, González \& Rodhouse 1998, Moore et al. 1998), depend primarily on mesopelagic fishes of the family Myctophidae (lanternfishes) which represent the second largest and most widely distributed biological resource in Antarctic waters (Sabourenkov 1991), with many species being circumpolar in distribution (Hulley 1990).

The Kerguelen Archipelago in the southern Indian Ocean is the summer breeding location of seabirds and seals, which in 1985 were estimated to consume approximately $462000 \mathrm{t}$ myctophids $\mathrm{yr}^{-1}$ (Guinet et al. 1996), equating to $26 \%$ of all prey consumed. Two of the primary consumers, Antarctic fur seals Arctocephalus gazella and king penguins Aptenodytes patagonicus, have increased in number by up to 7 -fold in this vicinity over the last 35 yr (Jouventin et al. 1982, Bester \& Roux 1986, Guinet et al. 1996, ChamailléJammes et al. 2000) and consequently, annual consumption rates are now undoubtedly considerably higher than the 1985 estimate. Abundant and predictable prey resources are a necessary requirement to support growing predator populations. The Kerguelen Archipelago is within close proximity of the PF, lying in the southern part of the PFZ (Park \& Gamberroni 1997), which is defined as the zone between the subAntarctic Front (SAF) to the north and the PF to the south (Klyausov 1990, Park et al. 1993). The productive waters of the PFZ, where Antarctic krill are absent, are likely to influence the foraging and breeding success of predators at Îles Kerguelen (Bocher et al. 2001).

Myctophids, associated with deep Antarctic waters throughout their life cycles (Kozlov \& Tarverdiyeva 1989), dominate the ichthyofauna within the southern PFZ near the Kerguelen Archipelago, with many species invading the surface layer at night (Duhamel et al. 2000) to feed on diurnally migrating meso- and macro- zooplankton. The general location of the ACC in this sector of the southern Indian Ocean is relatively stable owing to the influence of bottom topography (Park \& Gambéroni 1995); however, movements of the PF by several degrees of latitude between years occur intermittently (see Moore et al. 1999). Thus, the relative proximity of the Kerguelen Archipelago to the PF provides an opportunity to examine inter-annual variation in the diet of predators with respect to the effects of changing oceanographic features. Accordingly, we aimed to document the diet of Antarctic fur seals breeding at Îles Kerguelen over $3 \mathrm{yr}$, with a larger aim of examining possible differences in diet with reference to variation in oceanographic conditions and foraging behavior of fur seals, which will be examined in a future paper.

The majority of pinniped and particularly otariid diet studies have assessed prey composition by identifying hard parts, such as fish otoliths and squid beaks, remaining in feces (Green et al. 1990, Daneri \& Coria 1992, Reid \& Arnould 1996, Cherel et al. 1997) and/or regurgitates (Goldsworthy 1992, Fea \& Harcourt 1997, Kirkman et al. 2000). This method carries with it many biases in terms of the retention, digestion and erosion of prey hard parts. In feeding trials of several species of otariids, the recovery rates of otoliths have been found to be only 2 to $63 \%$ (Dellinger \& Trillmich 1988, Gales \& Cheal 1992, Fea \& Harcourt 1997, Lake 1997), while a study of Antarctic fur seals identified high individual variability in recovery rates (0 to $90 \%$; Staniland 2002) often with a complete absence of smaller fish otoliths (da Silva \& Neilson 1985). In addition, hard parts actually retrieved from scats may only represent the ingestion of prey during the previous feeding bout (Helm 1984, Jobling \& Breiby 1986, Staniland 2002). Several indirect methods are now being used to provide dietary information in addition to the conventional fecal analyses. Lipids, particularly fatty acids (FAs), may function as dietary indicators by comparing FA signatures of prey items and consequent comparison with predator tissues that are high in lipid, such as milk (Iverson 1993, Iverson et al. 1997, Brown et al. 1999) and adipose tissue (Raclot et al. 1998, Kirsch et al. 2000, Walton et al. 2000). This technique is based on the principle that unique arrays of FAs can be transferred largely unaltered up the food chain from prey to predator (Iverson et al. 1997, Raclot et al. 1998).

A secondary aim of the study was to compare dietary changes estimated by conventional scat analysis with the findings of signature FA analysis of fur seal milk samples. FA are derived primarily from immediate dietary intake (Iverson et al. 1997) and may represent dietary intake over a longer time span than scat analyses. Therefore, our secondary aim is to assess the usefulness of FA signature analysis (Iverson 1993) of fur seal milk in identifying longer-term dietary preferences than possible by 
conventional fecal analysis. To achieve this aim, milk FA signatures will be compared with FA profiles of a selection of possible prey items (see Lea et al. 2002b).

\section{MATERIALS AND METHODS}

Study site. The diet of female Antarctic fur seals breeding at Cap Noir, Îles Kerguelen $\left(49^{\circ} 07^{\prime} \mathrm{S}\right.$, $70^{\circ} 45^{\prime} \mathrm{E}$ ) was examined during February 1998, 1999 and 2000. The colony on the NE coast of the Courbet Peninsula comprised approximately 800 breeding female seals, which typically arrive at the colony in late November and usually give birth to a single pup, which they then suckle until weaning in late March or early April. The female's time ashore is interspersed with trips to sea of several days' duration to forage (Fig. 1).

Fecal analyses. Fecal samples of lactating fur seals were collected daily within the colony from areas used by adult females as well as from known seals upon their return to the colony whenever possible. Individual samples were frozen $\left(-20^{\circ} \mathrm{C}\right)$ on site and returned to the laboratory for sorting and prey identification. Samples were elutriated overnight and subsequently sieved through a $1 \mathrm{~mm}$ and $500 \mu \mathrm{m}$ mesh. The frequency of occurrence (FO) of fish (otoliths and bones), squid (beaks and eye lenses), invertebrates (amphipods, isopods, nematodes and annelids) and other miscellaneous items in feces was noted. Percentage FO is expressed as a percentage of the number of feces containing prey items. Otoliths (sagitta, asteriscus and lapillus) and squid beaks were sorted and identified to species level if possible, using the descriptions in Clarke (1986), Williams \& McEldowney (1990), Reid (1996) and our own reference collection at the CEBC (France). Subsequently, otolith length was measured from sagittal otoliths showing little or no sign of erosion. Standard length and biomass of fish species were calculated from the conversion of otolith length $(\mathrm{mm})$ using allometric equations (Adams \& Klages

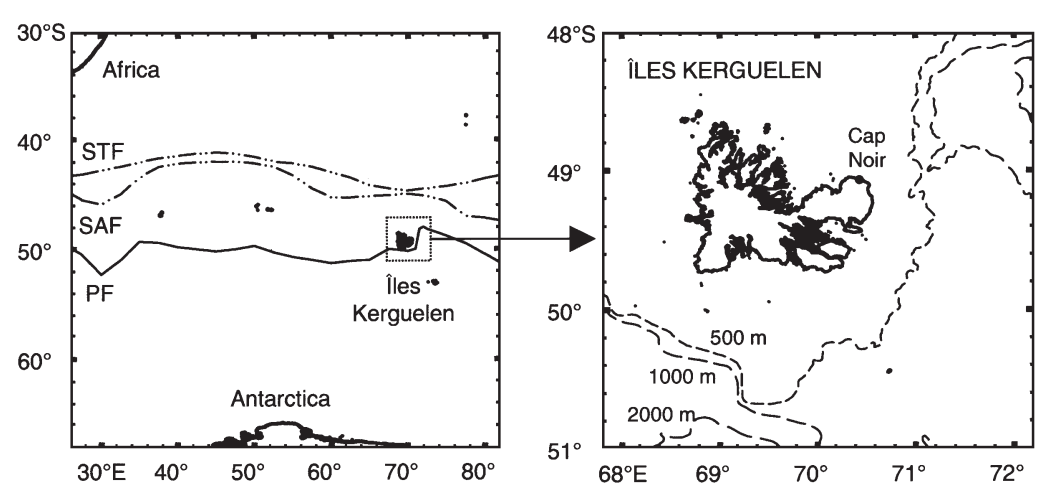

Fig. 1. Îles Kerguelen and oceanographic fronts of Southern Ocean. STF, sub-tropical front; SAF, sub-Antarctic front; PF, Polar Front
1987, Williams \& McEldowney 1990, Cherel et al. 1997, Olsson \& North 1997, Y. Cherel unpubl. data) for the majority of species. The conversion of lower rostral length to mantle length and squid body mass was achieved using allometric equations from Clarke (1986), Rodhouse et al. (1990) and Jackson (1995). In reconstructing the estimated fish biomass consumed by fur seals from scats, each otolith was considered to represent 1 fish, as there is little chance of all fish and therefore otoliths consumed by the fur seal being present in a particular scat.

Dietary energy value. The mean energetic value of the prey in each scat for the 3 yr was estimated using the calorific value of prey items ( $\mathrm{kJ} \mathrm{g}^{-1}$ wet mass). An estimate of the calorific content of the 8 major species of fish prey from the Kerguelen Plateau was available from Lea et al. (2002b), and for other species of myctophid from Cherel \& Ridoux (1992) and Tierney et al. (2002). In instances where the calorific value of a particular species was unknown, an estimate was used. A value of $5.4 \mathrm{~kJ} \mathrm{~g}^{-1}$, that of Champsocephalus gunnari from the Kerguelen Plateau, was assigned to other nonmyctophid fish prey in the absence of further data. The calorific content of Gonatus antarcticus (3.78 $\mathrm{kJ} \mathrm{g}^{-1}$ ) was taken from Clarke et al. (1985), and a value of $2.31 \mathrm{~kJ} \mathrm{~g}^{-1}$ was used for ammoniac squids and $4.25 \mathrm{~kJ} \mathrm{~g}^{-1}$ for muscular squids (Clarke et al. 1985).

FA analyses. Milk samples were collected from breeding female fur seals captured for the deployment or retrieval of time-depth recorders in February 1999 and 2000 (see Lea et al. 2002a), usually within $24 \mathrm{~h}$ of the female's arrival in the colony. The seals were injected with $1 \mathrm{ml}$ of $10 \mathrm{IU}$ Oxytocin (Herriot Agvet) intramuscularly upon capture. The milk was then manually extracted into two $2 \mathrm{ml}$ vials and frozen immediately at $-20^{\circ} \mathrm{C}$. In the laboratory, the milk samples were thawed, mixed and weighed.

The lipid was quantitatively extracted overnight by a modified (Bligh \& Dyer 1959) 1-phase methanol/chloroform/water extraction $(2 / 1 / 0.8, v / v / v)$. The phases were separated the following day by the addition of chloroform, water and sodium chloride $(1 / 1, v / v)$. Concentration of the total solvent extract was obtained by in vacuo rotary evaporation at $40^{\circ} \mathrm{C}$. A subsample of the extracted lipid was made up to a known concentration (typically around $0.01 \mathrm{~g} \mathrm{ml}^{-1}$ ) by the addition of chloroform and stored in the freezer $\left(-20^{\circ} \mathrm{C}\right)$. Lipid class analyses were conducted immediately; samples were stored for no more than $3 \mathrm{~d}$ in a known volume of chloroform. The quantity of lipid extracted per sample was used to calculate percentage lipid values.

An aliquot of the total lipid was analyzed using an Iatroscan MK V TH10 thin layer 
chromatography flame ionization detector (TLC-FID) analyzer (Iatron Laboratories) to determine the abundance of individual lipid classes (Volkman \& Nichols 1991). Peaks were quantified on an IBM-compatible computer using DAPA software (Dapa Scientific). Iatroscan results are generally reproducible to $\pm 10 \%$ (Volkman \& Nichols 1991).

An aliquot of the total lipid was treated with methanol/ hydrochloric acid/chloroform (10:1:1 v/v/v; $80^{\circ} \mathrm{C}, 2 \mathrm{~h}$ ). The FA methyl ester (FAME) products were extracted into hexane/chloroform $(4: 1 \mathrm{v} / \mathrm{v} ; 3 \times 1.5 \mathrm{ml})$ and after reduction under a stream of nitrogen, the FAME mixture was treated with $\mathrm{N}, \mathrm{O}$-bis-(trimethylsilyl)-trifluoroacetamide (BSTFA; $\left.50 \mu l, 60^{\circ} \mathrm{C}, 1 \mathrm{~h}\right)$ to convert sterols to their corresponding TMSi (trimethylsilyl) ethers. Gas chromatographic (GC) analyses of FAME were performed with a Hewlett Packard 5890A GC equipped with an HP-5 cross-linked methyl silicone fused silica capillary column $(50 \mathrm{~m} \times 0.32 \mathrm{~mm}$ in diameter), an FID, a split/splitless injector and an HP 7673A auto sampler; hydrogen was the carrier gas. Following the addition of methyl nonadecanoate and methyl tricosanoate internal standards, samples were injected in splitless mode at an oven temperature of $50^{\circ} \mathrm{C}$. After $1 \mathrm{~min}$, the oven temperature was raised to $150^{\circ} \mathrm{C}$ at $30^{\circ} \mathrm{C} \mathrm{min}^{-1}$, then to $250^{\circ} \mathrm{C}$ at $2^{\circ} \mathrm{C} \mathrm{min}^{-1}$ and finally to $300^{\circ} \mathrm{C}$ at $5^{\circ} \mathrm{C} \mathrm{min}^{-1}$.

Peaks were quantified with Waters Millennium software. Individual components were identified using mass spectral data and by comparing retention time data with those obtained for authentic and laboratory standards. GC results are subject to an error of $\pm 5 \%$ of individual component abundance.

Statistical analyses. All parametric statistical tests were performed using SYSTAT 9.0 (SYSTAT). Interannual comparisons of fish prey abundance identified from fecal analyses were conducted by Discriminant Function Analysis (DFA) of log+1-transformed abundance data. Otoliths not identified to species due to erosion were excluded. A backwards-stepwise DFA ( $\alpha$-level of 0.05 to remove) identified those species most influential in distinguishing the fish diet between years.

An analysis of covariance (ANCOVA) was performed on arcsine-transformed monounsaturated (MUFA) and polyunsaturated (PUFA) proportions for 1999 and 2000. Data were weighted according to MUFA proportions to account for the correlation between variables. Otherwise, the percentages of FAs identified in milk samples were compared interannually by $t$-test after arcsine transformation of the data, and a Bonferroni correction (Zar 1996) was applied to the significance level $(p<0.0014)$ to account for multiple comparisons and the possibility of significance occurring by chance. Those FAs identified as significantly different between years were then incor- porated in a backwards-stepwise DFA on arcsinetransformed proportion data to identify those FAs most important in differentiating between milk samples from different years. FA profiles of milk samples were compared with profiles of 12 possible prey species from the literature. We selected species present in the diet of fur seals at Îles Kerguelen, which were sampled from the Kerguelen Plateau region where possible, to compare inter-annual variation in diet between the 2 techniques. All values are reported as \pm SEM.

\section{RESULTS}

A total of 131 scats were collected in February over the 3 yr study, 60 in 1998, 24 in 1999 and 47 in 2000. Of those 131 scats, $83.2 \%$ contained fish otoliths (55 in 1998, 21 in 1999 and 33 in 2000). Fish comprised the majority of the diet in terms of FO in all 3 years (Table 1) with FO ranging from 90.9 to $94.9 \%$ of samples. Squid, while present in lower absolute numbers, were also found in the majority of scat samples (62.5 to $72.9 \%$ ). The presence of several species of crustaceans such as the amphipod Themisto gaudichaudii was evident from exoskeletons found in the fecal remains (Table 1). Nematodes were also common in samples, while small quantities of plastic were also present in $9.1 \%$ of scats sampled in 2000 .

\section{Fish prey}

In total, 3608 sagittal otoliths were found during the study averaging $38 \pm 33$ otoliths per scat (range 1 to 215 ). Otoliths from 25 fish species were identified in the scats over the 3 years (1998 to 2000), 16 of which were Myctophidae. Gymnoscopelus piabilis, Electrona subaspera and G. nicholsi accounted for $54.7 \%$ by number of the fish prey species identified in the mean diet of the fur seals (Table 2). A further $20.3 \%$ of otoliths were from the genus Gymnoscopelus or the family Myctophidae and were too eroded to reliably identify. Myctophids represented an average of $90.4 \%$ of prey hard parts identified in scats. Other species of fish accounted for $7.5 \%$ of prey items by number with Champsocephalus gunnari, the mackerel icefish, being the most numerous of these $(4.4 \%)$. Harpagifer spinosus, Scopelosaurus hamiltoni and the southern driftfish Icichthys australis followed in numerical abundance, all at less than $1 \%$.

\section{Cephalopod prey}

Six species of squid were found in the diet, with squid remains occurring in $67.7 \%$ of scat samples 
Table 1. Frequency of occurrence by number and percentage of prey items recorded in Antarctic fur seal scats at Cap Noir. Number of scats sampled and the number containing prey items are in parentheses

\begin{tabular}{|c|c|c|c|c|c|c|c|c|}
\hline \multirow[t]{2}{*}{ Prey type } & \multicolumn{2}{|c|}{$\begin{array}{c}1998 \\
(60 / 59)\end{array}$} & \multicolumn{2}{|c|}{$\begin{array}{c}1999 \\
(24 / 24)\end{array}$} & \multicolumn{2}{|c|}{$\begin{array}{c}2000 \\
(48 / 44)\end{array}$} & \multicolumn{2}{|c|}{$\begin{array}{c}\text { Total } \\
(132 / 127)\end{array}$} \\
\hline & $\mathrm{n}$ & $\%$ & $\mathrm{n}$ & $\%$ & $\mathrm{n}$ & $\%$ & $\mathrm{n}$ & $\%$ \\
\hline Fish & 56 & 94.9 & 22 & 91.7 & 40 & 90.9 & 118 & 92.9 \\
\hline Otoliths & 55 & 93.2 & 21 & 87.5 & 33 & 75.0 & 109 & 85.8 \\
\hline Eye lenses & 52 & 88.1 & 18 & 75.0 & 31 & 70.5 & 101 & 79.5 \\
\hline Bones & 48 & 81.4 & 20 & 83.3 & 37 & 84.1 & 105 & 82.7 \\
\hline Vertebrae & 49 & 83.1 & 16 & 66.7 & 26 & 59.1 & 91 & 71.7 \\
\hline Myctophids (scales or jaw bones) & 39 & 66.1 & 17 & 70.8 & 34 & 77.3 & 90 & 70.9 \\
\hline Channichthyids (jaw bones or opercles) & 13 & 22.0 & 1 & 4.2 & 0 & 0 & 14 & 11.0 \\
\hline Nototheniids (jaw bones) & 7 & 11.9 & 1 & 4.2 & 6 & 13.6 & 14 & 11.0 \\
\hline Paradiplospinus gracilis (teeth or vertebrae) & 4 & 6.8 & 1 & 4.2 & 0 & 0 & 5 & 3.9 \\
\hline Harpagifer spinosus (opercles) & 1 & 1.7 & 0 & 0.0 & 1 & 2.3 & 2 & 1.6 \\
\hline Cephalopods & 43 & 72.9 & 15 & 62.5 & 28 & 63.6 & 86 & 67.7 \\
\hline Beaks & 36 & 61.0 & 14 & 58.3 & 25 & 56.8 & 75 & 59.1 \\
\hline Eye lenses & 30 & 50.9 & 8 & 33.3 & 20 & 45.5 & 58 & 45.7 \\
\hline Gladii & 22 & 37.3 & 8 & 33.3 & 17 & 38.6 & 47 & 37.0 \\
\hline Radulae & 13 & 22.0 & 9 & 37.5 & 11 & 25.0 & 33 & 26.0 \\
\hline Crustaceans & 25 & 42.4 & 13 & 54.2 & 11 & 25.0 & 49 & 38.6 \\
\hline Themisto gaudichaudii & 18 & 30.5 & 5 & 20.8 & 5 & 11.4 & 28 & 22.1 \\
\hline Other amphipods & 9 & 15.3 & 6 & 25.0 & 0 & 0.0 & 15 & 11.8 \\
\hline Isopods & 2 & 3.4 & 1 & 4.2 & 1 & 2.3 & 4 & 3.2 \\
\hline Euphausiacae & 1 & 1.7 & 0 & 0.0 & 0 & 0.0 & 1 & 0.8 \\
\hline \multicolumn{9}{|l|}{ Others } \\
\hline Nematodes & 33 & 55.9 & 18 & 75.0 & 27 & 61.4 & 78 & 61.4 \\
\hline Pebbles & 18 & 30.5 & 16 & 66.7 & 23 & 52.3 & 57 & 44.9 \\
\hline Mollusk shells & 11 & 18.6 & 12 & 50.0 & 4 & 9.1 & 27 & 21.3 \\
\hline Plastic & 1 & 1.7 & 1 & 4.2 & 4 & 9.1 & 6 & 4.7 \\
\hline Annelids & 4 & 6.8 & 0 & 0.0 & 0 & 0.0 & 4 & 3.2 \\
\hline Feathers (penguin) & 1 & 1.7 & 0 & 0.0 & 0 & 0.0 & 1 & 0.8 \\
\hline
\end{tabular}

(Table 2). The ommastrephid squid Martialia hyadesi and Brachioteuthis ?riisei occurred most commonly, whilst Gonatus antarcticus, Moroteuthis ingens, $M$. knipovitchi and?Mastigoteuthis A (Clarke) were also present in lower numbers (Table 2). The squid component of the diet comprised on average only $2.1 \%$ of the diet by number.

Inter-annual variation in number and size of prey

The number of fish and squid species identified in the diet of seals was highest in 1998 at 33 species, with 21 and 22 species identified in 1999 and 2000 respectively. A prey diversity index was calculated on an individual scat basis (number of fish and squid species groups per scat) and averaged for each year. The prey index did not vary significantly between years $(5.4 \pm 0.3, \mathrm{n}=110$, range 1 to 13) for those scats containing diagnostic hard parts ( 1 -way ANOVA, $F_{107,2}=2.037, \mathrm{p}=0.135$ ). However, if the prey indices for all scats were used, i.e. including those scats with no prey, the index was significantly lower in 2000 (3.2 \pm 0.5, 1-way ANOVA, $\left.F_{129,2}=6.027, \mathrm{p}<0.05\right)$ than in 1998 and $1999(4.9 \pm 0.4$ and $5.8 \pm 0.8$, respectively). The high proportion of empty scats in 2000 (31.3\%) as opposed to other years (both $8.3 \%$ ), explains this finding.

Fish-Lanternfish comprised 85.6, 97.8 and $97.6 \%$ of the fish component of the diet in each of the 3 years respectively $(\bar{x}=93.7 \%)$. Gymnoscopelus piabilis was the main prey species consumed in all years. Similar proportions of the 3 most common fish prey species (G. piabilis, G. nicholsi and Electrona subaspera) were consumed by seals in all years, although G. nicholsi was more prevalent in 2000 than in 1998 and 1999. The importance of some of the minor prey species varied considerably between years (Table 2). The mackerel icefish Champsocephalus gunnari was of variable importance in the diet, only being present in 1998 where it represented approximately $10 \%$ by number (Table 2). E. carlsbergi also occurred only in 1998, while Protomyctophum choriodon and P. tenisoni were present in higher numbers in 1999. The mean number of otoliths per scat (33.4 \pm 3.65$)$ did not vary significantly between years (1-way ANOVA, $F_{105,2}=2.123, p=0.125$ ) with considerable variation occurring in numbers of otoliths between scats (0 to 215 ). 


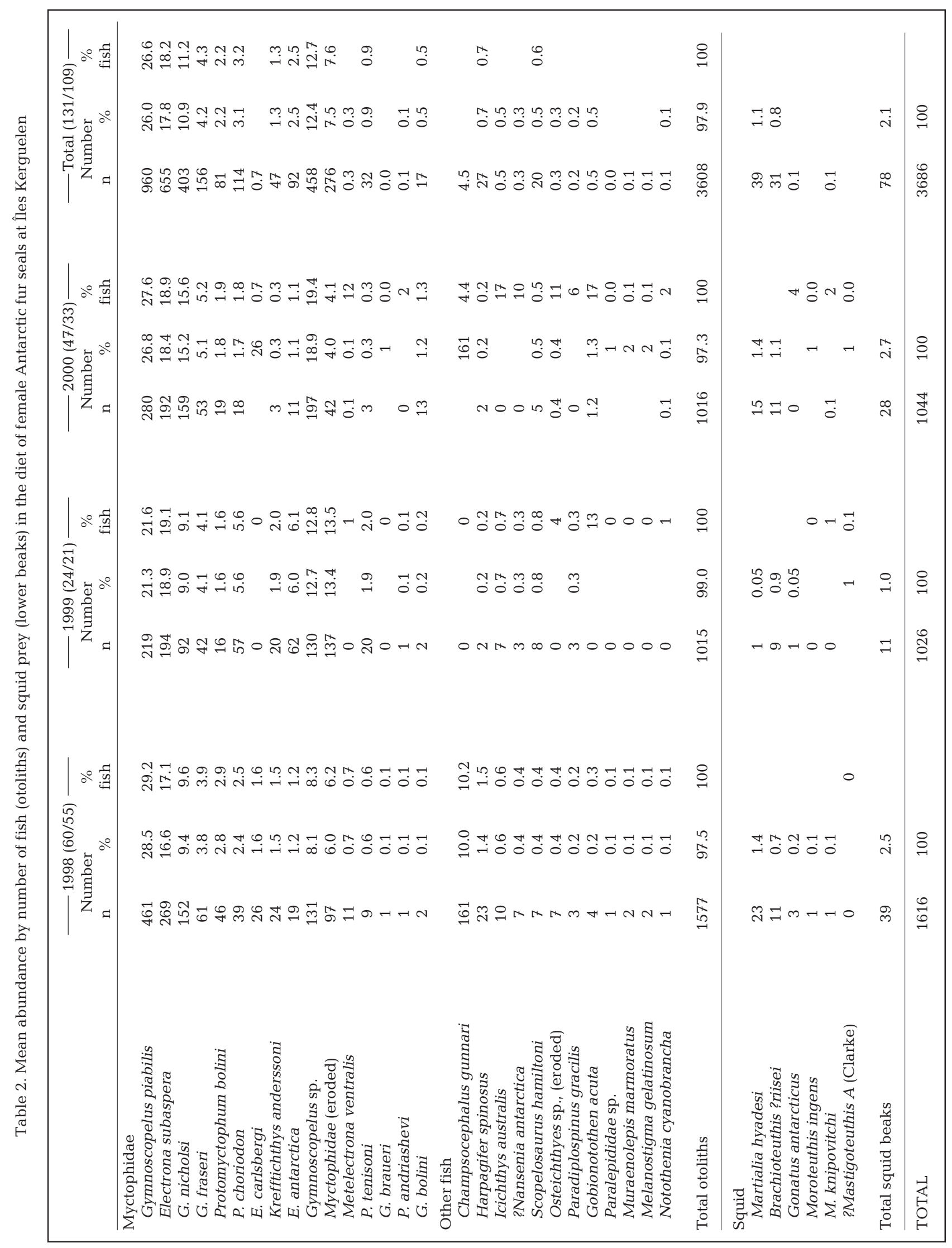


An inter-annual difference in dietary composition was detected by a complete linear DFA of logtransformed abundance data (Wilks' Lambda $=0.452$, $F_{162,48}=$ ca. 1.646, $p=0.012$ ). A plot of the canonical scores is illustrated in Fig. 2, indicating a high degree of overlap between years, particularly in 2000. A backwards-stepwise DFA conducted on the same data indicated that 2 species, Protomyctophum tenisoni and Champsocephalus gunnari, were largely responsible for the distinction in diet between years (Wilks' Lambda $=0.794, F_{206,4}=$ ca. $\left.6.292, \mathrm{p}=0.001\right)$. Using these 2 species as discriminators, an average $44 \%$ of scats were correctly assigned to the year by the Jackknife classification matrix (Table 3 ). The fact that $90 \%$ of samples collected in 2000 were correctly assigned, in comparison to the lower percentages for 1998 (22\%) and 1999 $(33 \%)$, indicates that although differences between years were evident, a core diet was present in all years and comprised the majority of the diet in 2000 (Fig. 2).

Otolith sizes of the 3 most common species of fish prey (Fig. 3) were compared between years by 1-way ANOVA. Gymnoscopelus nicholsi were smaller in 1999 than in 1998 and $2000\left(F_{145,2}=13.104, \mathrm{p}<0.001\right)$, Electrona subaspera were larger in 1999 than in 2000, while fish consumed in 1998 were intermediate $\left(F_{117,2}=\right.$ 7.549, $\mathrm{p}=0.001)$. G. piabilis were similar in size in all years (Table 4), although the distribution of fish sizes in 1998 was skewed more toward fish of greater than $120 \mathrm{~mm}$ length. The majority of myctophid fish preyed upon by Arctocephalus gazella were juveniles excepting G. piabilis in all years, and E. antarctica and Protomyctophum tenisoni in 2000.

Champsocephalus gunnari consumed in 1998 ranged in size from 175.3 to $210.1 \mathrm{~mm}$ (mean $192.9 \pm$

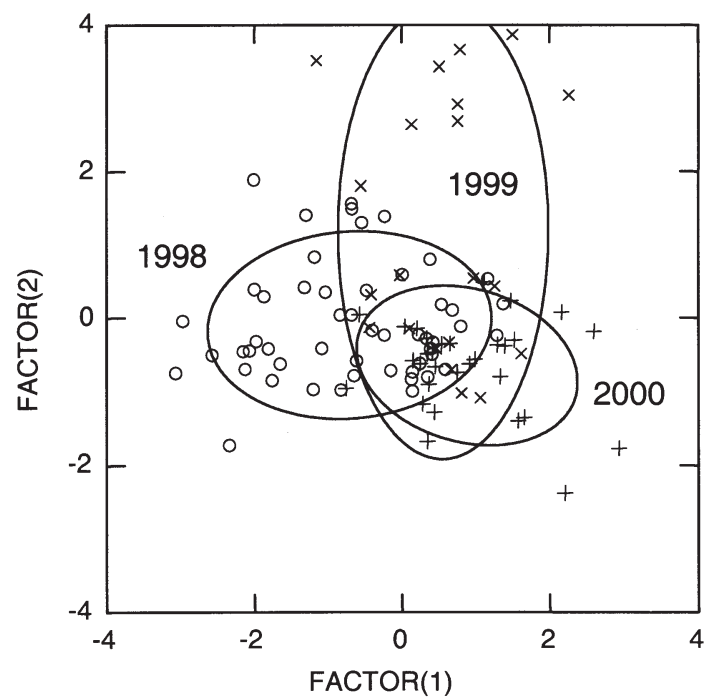

Fig. 2. Prey composition canonical scores plot by number in $1998(0), 1999(\times)$ and $2000(+)$
Table 3. Discriminant function analysis stepwise (SCM) and Jackknife (JCM) classification matrices of fish abundance by number in 1998, 1999 and 2000

\begin{tabular}{|lrrrrc|}
\hline & & 1998 & 1999 & 2000 & $\%$ correct \\
\hline SCM & 1998 & 13 & 5 & 37 & 24 \\
& 1999 & 0 & 7 & 14 & 33 \\
& 2000 & 0 & 3 & 28 & 90 \\
& Total & 13 & 15 & 79 & 45 \\
JCM & 1998 & 12 & 6 & 37 & 22 \\
& 1999 & 0 & 7 & 14 & 33 \\
& 2000 & 0 & 3 & 28 & 90 \\
& Total & 12 & 16 & 79 & 44 \\
\hline
\end{tabular}

$9.8 \mathrm{~mm}$ ) indicative of fish at age 1+ from the September 1996 cohort (G. Duhamel pers. comm.).

Cephalopods - The overall abundance of squid was generally low, however of the 2 more prevalent species, Martialia hyadesi occurred in 1998 and 2000 in similar proportions (1.4\%), whilst Brachioteuthis ? riisei was present in all years at 0.7 to $1.1 \%$ of the diet.

Lower rostral lengths (LRL) of Martialia hyadesi squid beaks were compared between 1998 (3.74 \pm $0.4 \mathrm{~mm})$ and $2000(4.33 \pm 0.5 \mathrm{~mm})$ by Student's $t$-test as only 1 individual was present in 1999. Beaks of M. hyadesi were significantly larger in 2000 than those consumed in $1998\left(t_{0.05[36]}=2.042, \mathrm{p}<0.001\right)$. The LRL of Brachioteuthis ?riisei were compared in all 3 years by ANOVA, with squid in 1998 (LRL = 2.43 $\pm 0.5 \mathrm{~mm}$ ) being significantly larger than those in 2000 (LRL = $\left.1.8 \pm 0.5 \mathrm{~mm}_{;} F_{2,30}=5.109, \mathrm{p}<0.05\right)$, while the length of $B$. ?riisei taken in 1999 was intermediate (LRL = $2.02 \pm 0.4 \mathrm{~mm}$; Table 4).

\section{Reconstituted mass and calorific value of prey}

Myctophids also dominated the diet in terms of reconstituted mass, accounting for 54,74 and $82 \%$ of biomass in 1998, 1999 and 2000, respectively. In total, the 3 most commonly occurring species (Gymnoscopelus piabilis, G. nicholsi and Electrona subaspera) represented 42 to $51 \%$ of the reconstituted mass, whilst G. piabilis alone consistently represented approximately $30 \%$ of biomass (Table 4 ). Some species accounted for a considerably higher proportion of the diet in terms of reconstituted mass than by number, such as the mackerel icefish (17\% cf. 10\%) and the Southern driftfish Icichthys australis in 1999 (22\% cf. $0.7 \%$ ) owing to their large size (mean mass $620 \mathrm{~g}$ ).

Although reconstituted biomass and energy content of the diet are not quantitative measures, particularly when calculated from fecal remains, inter-annual comparisons of these measures are of interest. Prey bio- 


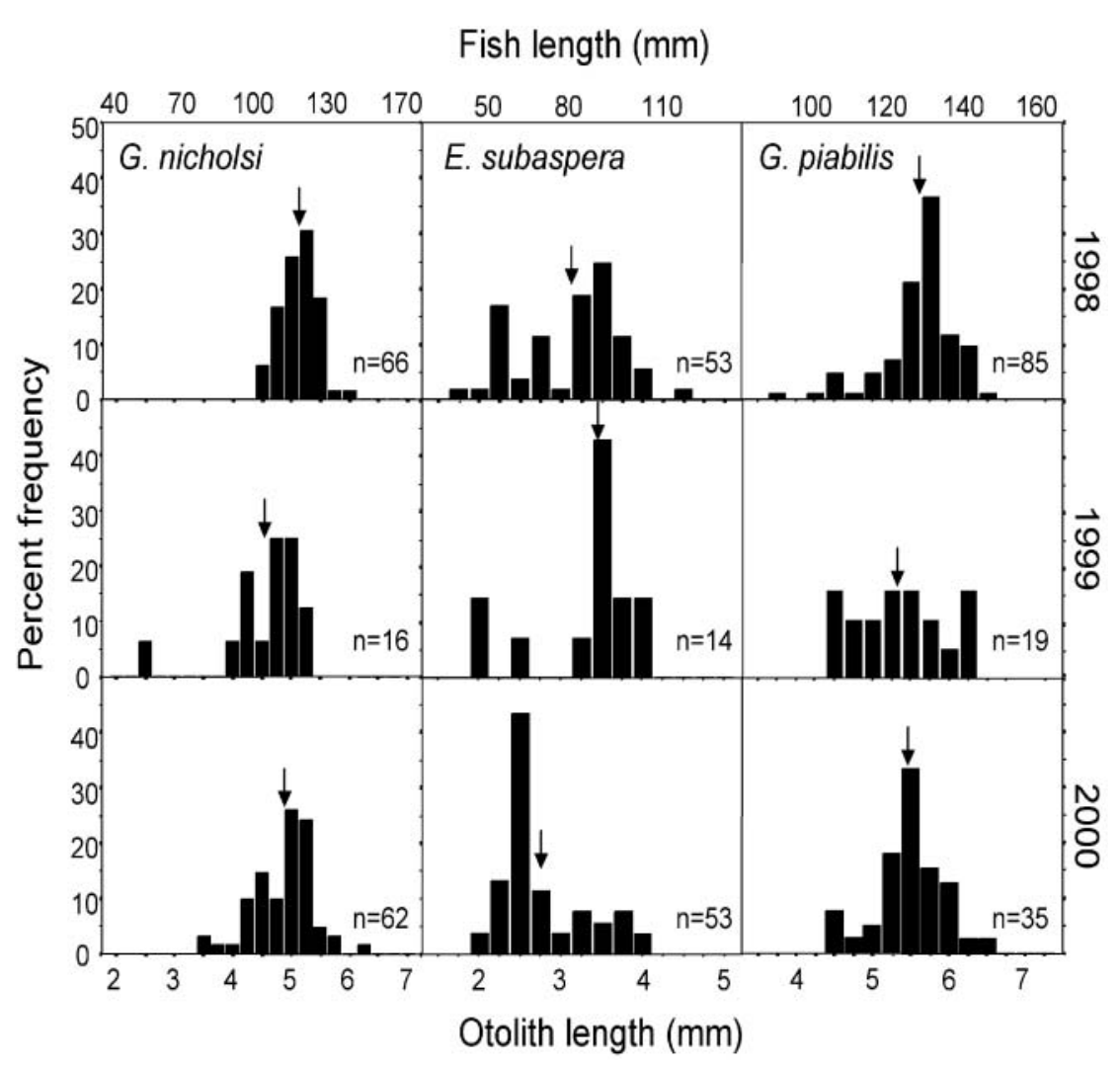

Fig. 3. Percent frequency histograms of otolith and total fish length for Gymnoscopelus piabilis, G. nicholsi and Electrona subaspera. Arrows denote mean otolith or fish length of a minimum 99\% triacylglycerides (TAGs) and small amounts of polar lipid and sterols. The major FAs in Antarctic fur seal milk were 18:1 19 (25 to $38 \%$ ),

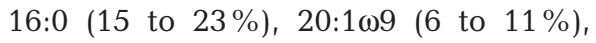
$22: 6 \omega 3$ (1 to $10 \%), 16: 1 \omega 7$ (5 to $8 \%$ ), $20: 5 \omega 3$ ( 1 to $8 \%$ ) and $18: 1 \omega 7$ (4 to $7 \%$ ). Monounsaturated FAs (MUFAs; 50 to $63 \%$ ) were more prevalent than either polyunsaturated FAs (PUFAs; 6 to $24 \%$ ) and saturated FAs (22 to $33 \%$ ).

\section{Intra-individual variation in milk lipid composition}

To evaluate the possibility of shortterm temporal variation in milk FA composition, the FA profiles of milk samples collected before and after 1 or 2 foraging trips for 13 females were compared. A Pearson's correlation coefficient (PCC) was calculated for each pair of milk samples and regressed against the number of days between milk samples (Fig. 4a,b). The correlation between FA composition of pre- and postforaging trip milk samples was high (mean PCC $=0.995 \pm 0.005)$. However, no relationship was apparent between the number of days between samples, which ranged between 7.8 and $18.9 \mathrm{~d}\left(\mathrm{r}^{2}\right.$

mass per scat $(763 \pm 77 \mathrm{~g})$ did not differ between years when compared by 1 -way ANOVA $\left(F_{105,2}=0.382, \mathrm{p}=\right.$ 0.683). Prey energy value per scat was similar between years (1-way ANOVA, $F_{105,2}=0.368, p=0.693$ ) at $5070 \pm 522 \mathrm{~kJ}$, with much variation evident between scats (33 to $33674 \mathrm{~kJ}$ ). Energy value per scat was positively related to the reconstituted mass per scat for all 3 years $\left(r^{2}=0.901\right.$ to $\left.991, p<0.05\right)$. The slopes of the relationship were tested for year effects by ANCOVA. Scats in 1998 constituted less energy per $g$ of reconstituted prey biomass than those from 1999 and 2000 $\left(F_{104,2}=2.910, \mathrm{p}=0.059\right)$.

\section{Milk lipid and FA analyses}

Antarctic fur seal milk is generally rich in lipid content, ranging from 28.1 to $68.7 \%$ of wet mass. The mean lipid content of milk sampled during late lactation $1999(43.3 \pm 7.1 \%, \mathrm{n}=22)$ was significantly lower than the $53.2 \pm 6.8 \%$ recorded in $2000\left(\mathrm{n}=16, t_{36[0.05]}=\right.$ -4.361 pooled variance, $\mathrm{p}<0.001$ ). Lipid class analyses of 20 milk samples indicated that milk was comprised
$=0.035, \mathrm{p}>0.05)$ and the $\mathrm{r}$ correlation co-efficient. Thus, it would appear that there is little intra-individual variation in milk FA composition over a 1 to $3 \mathrm{wk}$ time span.

\section{Inter-annual variation in milk FA profiles}

The FA profiles of seal milk in February-March 1999 ( $\mathrm{n}=22$ ) and 2000 ( $\mathrm{n}=16$ ) were variable both within and between years (Table 5). The relationship between MUFA and PUFA levels in the 2 years was significantly different (ANCOVA, $F_{35,1}=22.354$, p < 0.05), with milk samples being higher in PUFAs in 1999 $(21.4 \%)$, while in 2000 milk was more variable in composition with several seals having a particularly high occurrence of MUFAs (Fig. 5). In 1999, relative proportions of 22:6 $\omega 3$ (DHA) overall PUFA levels were higher than in 2000 (see Table 5 for test-results), whilst the abundance of saturated FA and 16:1 $107,18: 1 \omega 7$ and 20:1 $\omega 9$ was greater in 2000 (Table 5). The ratio of essential $\omega 6$ to $\omega 3$ FA $(6.1 \pm 0.6)$ was significantly lower in 2000 than in $1999\left(7.9 \pm 0.4 ; t_{36,[0.05]}=2.63, \mathrm{p}<0.05\right)$. 


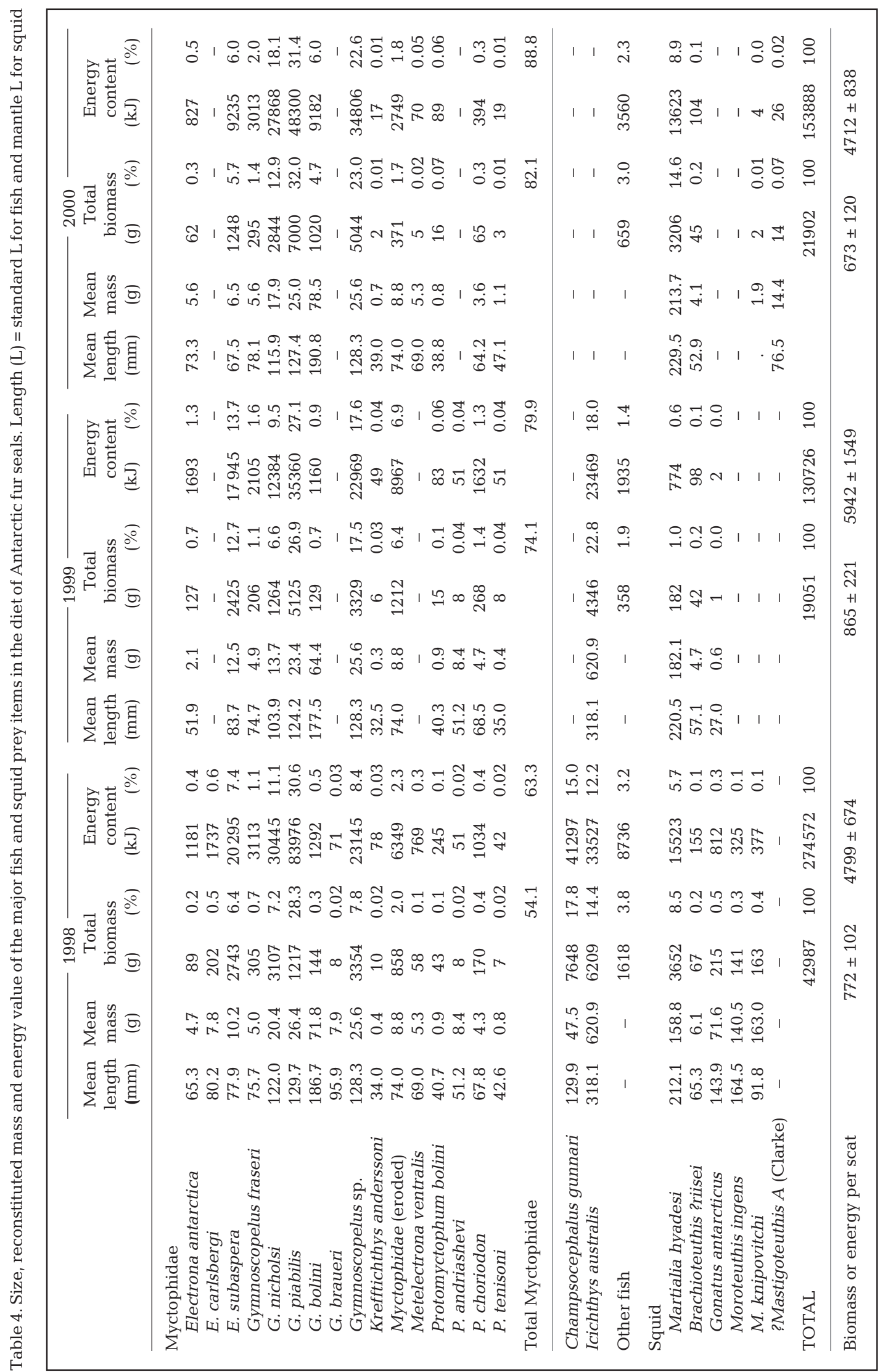



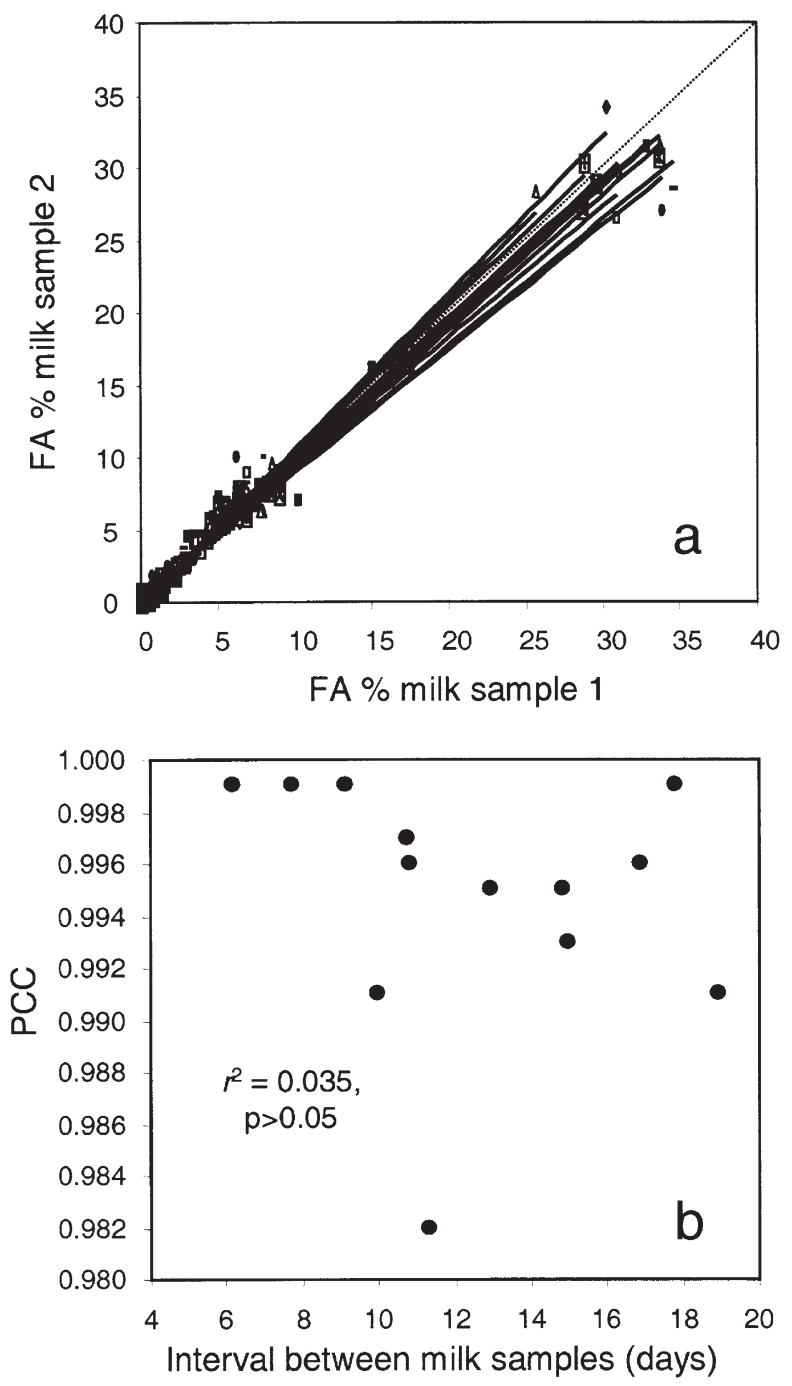

Fig. 4. (a) Correlation between paired milk samples from 13 Antarctic fur seals. Dotted line denotes a 1:1 slope; (b) regression of Pearson's correlation co-efficient (PCC) against sampling interval between milk sample collections

\section{Dietary implications of FA analysis}

The proportional abundance of 19 FAs in the milk samples differed significantly between years (Table 5). Of those 19 FAs, 9 were identified by a backwards-

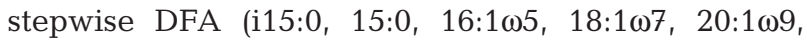

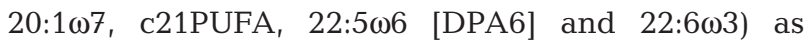
contributing to a significant inter-annual difference between milk samples (Wilks' Lambda $=0.1174, F_{9,28}=$ ca. 23.40, p < 0.01). Samples from the different years were correctly re-assigned to year in $100 \%$ of cases using both a standard classification matrix and a Jackknife classification matrix.

The relative abundance of the 9 influential FAs identified by DFA were compared between the 12 potential prey items, which included 3 species of squid from the Southern Plateau (SP) and Heard Island (HI): Martialia hyadesi (SP), Moroteuthis knipovitchi (HI) and Gonatus antarcticus (HI) (K. Phillips only unpubl. data); 7 species of myctophid (Electrona carlsbergi, E. subaspera, Gymnoscopelus piabilis, G. fraseri, G. nicholsi; Protomyctophum tenisoni) and Champsocephalus gunnari from the Kerguelen Plateau (Lea et al. 2002b), and the crustacean Themisto gaudichaudii (Phleger et al. 1998) from the Elephant Island region, Antarctica. The relative proportions of 6 of the FAs were higher in milk samples in 2000 (Table 6). The FA i15:0, for which the highest $t$-value was recorded in inter-annual comparisons of milk samples, was highest in 2 of the common fish prey species (G. piabilis and E. subaspera) in addition to $G$. fraseri and $P$. tenisoni (Lea et al. $2002 \mathrm{~b})$; however, it was present only at very low levels $(<0.5 \%)$ in milk samples (Table 2$)$. The monounsaturated 18:1 $107 \mathrm{FA}$ was unique in that the only prey item with high levels of this FA was $G$. nicholsi, which was more common in the diet of seals in 2000 (13.3\%), in terms of prey biomass, than in 1999 (6.6\%). Both

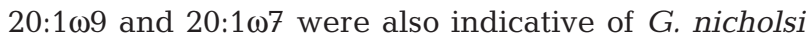
to a lesser extent.

Of the 3 FAs occurring in higher proportions in

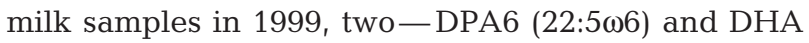

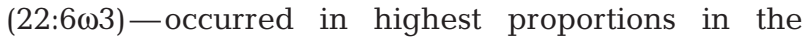
ommastrephid squid Martialia hyadesi. Abundance of this species was much reduced in scats from 1999 (Table 2); however, total FO of squid remains was similar between years at approximately $63 \%$. Thus, the relatively high proportions of both these FAs in 1999 may indicate the presence of $M$. hyadesi in the diet over a longer time span than scat analysis is capable of detecting. However, 22:6 $\omega 3$ is also present in reasonable quantities in the amphipod Themisto gaudichaudii and Protomyctophum tenisoni, both of which were more common in the diet in 1999 and are rich in PUFA.

\section{DISCUSSION}

\section{Limitations and assumptions of dietary techniques}

There are many assumptions for all methods used to quantify the diet of a predator feeding at sea. Several studies have highlighted the errors associated with differential rates of digestion in relation to the hard parts of prey, particularly otoliths and squid beaks (Jobling \& Breiby 1986, Pierce \& Boyle 1991, Gales \& Cheal 1992). Recent diet studies of sub-Antarctic fur seals Arctocephalus tropicalis at Marion Island have found that scat analysis indicated a diet rich in myctiophids (Klages \& Bester 1998), whilst analyses of stomach contents for the same species at Marion (Ferreira \& Bester 1999) and 
Gough Islands (Bester \& Laycock 1985) revealed a predominance of squid in the diet. Unfortunately, it is very difficult to account for many of these problems when studying free-ranging marine predators without the lethal take of individuals. However, as our primary aims were to identify variability in the diet over several years, many of the elements that make dietary quantification difficult, as mentioned above, should remain constant over time, thereby enabling a comparative study such as ours to draw conclusions about relative change with some confidence. By utilizing 2 techniques of dietary assessment, we have shown that whilst female Antarctic fur seals prey primarily on myctophids at Cap Noir, Îles Kerguelen, species composition of their diet varies significantly between years most probably in response to changes in prey availability affected by inter-annual shifts in the positioning of oceanic frontal structures and associated marine productivity.
Table 5. Fatty acid (FA) composition (\% contribution of total FA content) of Antarctic fur seal milk in late lactation for 1999 and 2000. MUFA, monounsaturated FAs; PUFA, polyunsaturated FAs; SAT, saturated FAs. Values are mean $\pm \mathrm{SE}$

\begin{tabular}{|c|c|c|c|c|}
\hline FAs & 1999 & 2000 & $t$ & $\mathrm{p}$ \\
\hline $14: 0$ & $3.69 \pm 0.11$ & $4.56 \pm 0.20$ & 4.156 & 0.0001 \\
\hline $15: 0$ & $0.33 \pm 0.01$ & $0.38 \pm 0.02$ & 3.458 & 0.001 \\
\hline $16: 0$ & $16.53 \pm 0.10$ & $18.63 \pm 0.52$ & 4.639 & 0.0001 \\
\hline $18: 0$ & $2.79 \pm 0.04$ & $3.35 \pm 0.11$ & 5.517 & 0.0001 \\
\hline $20: 0$ & $0.14 \pm 0.00$ & $0.17 \pm 0.01$ & 3.594 & 0.001 \\
\hline i15:0 & $0.18 \pm 0.00$ & $0.26 \pm 0.01$ & 6.476 & 0.0001 \\
\hline a15:0 & $0.05 \pm 0.00$ & $0.07 \pm 0.01$ & 4.049 & 0.0001 \\
\hline 4,8,12TMTD & $0.07 \pm 0.00$ & $0.10 \pm 0.01$ & 3.756 & 0.001 \\
\hline SAT total & $(23.79 \pm 0.17)$ & $(27.52 \pm 0.84)$ & -5.038 & 0.0001 \\
\hline $14: 1 \omega 5$ & $0.15 \pm 0.05$ & $0.19 \pm 0.01$ & & \\
\hline $16: 1 \omega 9$ & $0.43 \pm 0.03$ & $0.41 \pm 0.02$ & & \\
\hline $16: 1 \omega 7$ & $5.98 \pm 0.10$ & $6.67 \pm 0.16$ & 3.818 & 0.0001 \\
\hline $16: 1 \omega 5$ & $0.25 \pm 0.00$ & $0.33 \pm 0.01$ & 5.529 & 0.0001 \\
\hline $17: 1$ & $0.40 \pm 0.01$ & $0.37 \pm 0.01$ & & \\
\hline $18: 1 \omega 9$ & $29.79 \pm 0.57$ & $27.96 \pm 0.77$ & & \\
\hline $18: 1 \omega 7$ & $5.12 \pm 0.12$ & $5.96 \pm 0.11$ & 4.895 & 0.0001 \\
\hline $18: 1 \omega 5$ & $0.58 \pm 0.01$ & $0.64 \pm 0.02$ & 3.677 & 0.001 \\
\hline $20: 1 \omega 9$ & $8.47 \pm 0.23$ & $9.60 \pm 0.22$ & 3.504 & 0.001 \\
\hline $20: 1 \omega 7$ & $0.50 \pm 0.01$ & $0.60 \pm 0.02$ & 5.269 & 0.0001 \\
\hline $22: 1 \omega 11$ & $1.21 \pm 0.07$ & $1.56 \pm 0.12$ & & \\
\hline $22: 1 \omega 9$ & $0.92 \pm 0.04$ & $1.06 \pm 0.05$ & & \\
\hline $22: 1 \omega 7$ & $0.11 \pm 0.01$ & $0.17 \pm 0.01$ & 4.048 & 0.0001 \\
\hline $24: 1$ & $0.58 \pm 0.01$ & $0.84 \pm 0.07$ & & \\
\hline MUFA total & $\left(54.92^{\mathrm{a}} \pm 0.49\right)$ & $(56.37 \pm 0.92)$ & & \\
\hline $\mathrm{C}_{16}$ PUFA & $0.28 \pm 0.02$ & $0.33 \pm 0.01$ & & \\
\hline $18: 3 \omega 6$ & $0.07 \pm 0.00$ & $0.16 \pm 0.03$ & 3.973 & 0.0001 \\
\hline $18: 4 \omega 3$ & $1.04 \pm 0.05$ & $0.85 \pm 0.04$ & & \\
\hline $18: 2 \omega 6$ & $1.12 \pm 0.07$ & $1.00 \pm 0.06$ & & \\
\hline $20: 4 \omega 6$ & $0.63 \pm 0.02$ & $0.50 \pm 0.05$ & & \\
\hline $20: 3 \omega 6$ & $0.19 \pm 0.00$ & $0.17 \pm 0.01$ & & \\
\hline $20: 4 \omega 3$ & $0.97 \pm 0.03$ & $1.20 \pm 0.08$ & & \\
\hline $20: 5 \omega 3$ & $6.39 \pm 0.17$ & $4.67 \pm 0.58$ & & \\
\hline $20: 2 \omega 6$ & $0.28 \pm 0.01$ & $0.29 \pm 0.01$ & & \\
\hline $22: 5 \omega 6$ & $0.10 \pm 0.00$ & $0.06 \pm 0.01$ & 3.614 & 0.001 \\
\hline $\mathrm{C}_{21}$ PUFA & $0.46 \pm 0.02$ & $0.35 \pm 0.03$ & 4.490 & 0.0001 \\
\hline $22: 6 \omega 3$ & $7.80 \pm 0.34$ & $4.97 \pm 0.73$ & 3.895 & 0.0001 \\
\hline $22: 5 \omega 3$ & $2.07 \pm 0.07$ & $1.57 \pm 0.19$ & & \\
\hline PUFA total & $(21.37 \pm 0.55)$ & $(16.11 \pm 1.52)$ & 3.632 & 0.001 \\
\hline$\sum \omega 3$ & $(18.26 \pm 0.56)$ & $(13.25 \pm 1.48)$ & & \\
\hline$\sum \omega 6$ & $(2.38 \pm 0.08)$ & $(2.18 \pm 0.10)$ & & \\
\hline Ratio $\omega 3: \omega 6$ & $(7.92 \pm 0.40)$ & $(6.05 \pm 0.63)$ & 2.632 & 0.012 \\
\hline
\end{tabular}

\section{Diet composition}

The importance of fish, particularly myctophids, as the main prey items of Antarctic fur seals at the Kerguelen Archipelago was confirmed by fecal analyses and supports the previous findings of Cherel et al. (1997) and Guinet et al. (2001). Myctophids, which inhabit the Antarctic PFZ (Duhamel et al. 2000), dominated the diet in February in all 3 years, both by number and reconstitu-ted mass. Gymnoscopelus piabilis was consistently the most common species present in the diet. This species is also present in the diet of conspecifics at Macquarie Island and Marion Island (Goldsworthy et al. 1997, Klages \& Bester 1998, Robinson et al. in press) and king penguins at the Crozet Archipelago (Cherel et al. 1996), and has even been reported in the diet of New Zealand fur seals in the temperate waters of southern Tasmania (Lake 1997). In addition to G. piabilis, Electrona subaspera and G. nicholsi were consistently important in the diet. These species are mesopelagic/ epibenthic (Hulley 1990) and are present in the upper part of the mesopelagic fish community of the PFZ, being absent in daytime trawls at $300 \mathrm{~m}$ and abundant at the surface at night (Duhamel et al. 2000). The behavior of female Antarctic fur seals foraging nearby Îles Kerguelen is apparently determined by the diurnal movements of their prey. Antarctic fur seals typi-cally dive nocturnally, commencing at considerable depth, with dives gene-rally becoming progressively shallower throughout the night in conjunction with what is assumed to be the simultaneous migration of prey (Lea et al. 2002).

Gymnoscopelus piabilis is large in comparison to other myctophids and high in calorific value (Raclot et al. 1998), and may therefore be an advantageous species in terms of efficient energy consumption during lactation for Antarctic fur seals. The diet of Antarctic fur 
abundance around Bird Island (Reid \& Arnould 1996). North (1996) observed 2 size classes of C. gunnari in the diet of fur seals over winter with the majority of those taken coinciding with the size classes trawled by the fishery ( 225 to $325 \mathrm{~mm}$ ). At Heard Island, 2 peaks were detected at 195 and $225 \mathrm{~mm}$ in winter and summer, respectively (Green et al. 1997), coinciding with the size of fish taken by seals at Îles Kerguelen in 1998. C. gunnari was not present in the diet in either 1999 or 2000 at îles Kerguelen, although research trawls caught low numbers of 244 and $313 \mathrm{~mm}$ sized fish in the 2 years, respectively (Claudet 2001). The consumption of icefish in 1998 may reflect either the reduced availability and/or catchability of myctophids close to the archipelago in this year, or more patchily distributed icefish in 1999 and 2000.

Cephalopod beaks were common in seal scats, although they occurred in low numbers when compared to the quantities fish prey consumed, accounting for only $2.1 \%$ of prey by number. At least 4 of the squid species taken by Antarctic fur seals are associated with waters of the PFZ and are known to feed on myctophids (Rodhouse \& White 1995, González \& Rodhouse 1998, Phillips et al. 2001). Only juvenile Martialia hyadesi, $M$. ingens and M. knipovitchi (Kubodera et al. 1998, Wormuth 1998) were taken by seals foraging in the Kerguelen region. Given the low numbers of squid present in the diet, it is probable that squid were either taken opportunistically as seals and squid fed on nocturnal myctophid aggregations, or the squid were patchier in their distribution than myctophids. Studies of Antarctic fur seals at other breeding sites confirm the relative paucity of cephalopods in the diet (Klages 1996, Goldsworthy et al. 1997, Daneri et al. 1999, Kirkman et al. 2000), contrary to studies of more temperate species such as the New Zealand and Australian fur seals (Gales et al. 1993, Fea \& Harcourt 1997). In any event, the occurrence of cephalopods in the diet of Antarctic fur seals was low and never accounted for more than $2.1 \%$ of the diet by number, a figure that would be over-estimated by the preferential retention of squid beaks (see Klages \& Bester 1998, Ferreira \& Bester 1999). However, in years where squid were consumed, such as 1998 and 2000, the biomass and energy value of this prey was considerable, ranging from 10 to $15 \%$ of reconstituted biomass.

\section{Milk lipids as indicators of dietary variation}

The dietary dependence of fur seals on myctophids during late lactation was further supported by the high levels of MUFAs present in the FA profiles of fur seal milk. Myctophidae generally have high levels of MUFAs (Seo et al. 1996, Raclot et al. 1998), which may be transferred directly to predators, as shown by the close relationship between the FAs of king penguin subdermal fat and of their myctophid diet (Raclot et al. 1998). The percentage of MUFAs in fur seal milk (53 to $55 \%$ ) more closely approximates that of TAG-rich myctophids rather than those species rich in wax esters, such as Electrona antarctica or Gymnoscopelus braueri (Phleger et al. 1999), thus supporting the findings of the fecal analyses. High levels of 18:1 $\omega 9,20: 1 \omega 9$

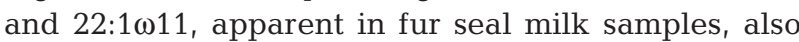
tend to be characteristic of many teleost fish (Reinhardt \& van Vleet 1986, Iverson et al. 1997).

Milk secreted later in lactation is thought to contain FAs representative of dietary intake, whilst FAs present in blubber stores during the peri-natal period may represent dietary intake over winter prior to parturition (Iverson 1993, Iverson et al. 1997). Mammalian milk composition varies according to lactation stage (Oftedal 1984). Consequently, milk samples for this study were collected in the same season for both years, in order to reduce the effect of any compositional differences related to lactation stage or season. Thus, the differences observed in the FAs composition of milk samples in 2 consecutive years in this study confirm the inter-annual shift in diet detected by fecal analysis.

The similarity of milk samples from the same seal collected up to $19 \mathrm{~d}$ apart suggests that seals may feed on similar prey during successive trips, therefore exhibiting little change in their milk FA profiles. Alternatively, milk FAs may be indicative of dietary intake over at least $19 \mathrm{~d}$ and FA profiles are therefore not particularly responsive to short-term changes in prey consumption. Little information is available on short-term dietary preferences, although Bonadonna et al. (2001) have recently shown that fur seals at Cap Noir often maintain the direction of travel used in the preceding trip, perhaps foraging on the same prey. However, in either scenario, it is probable that milk FA compositional profiles represent longer-term dietary intake, at least up to $3 \mathrm{wk}$, than fecal analyses.

Milk samples collected during late lactation 1999 were high in PUFAs $(21.4 \%$ cf. $16.1 \%)$, whilst samples from 2000 where higher in saturated FAs and MUFAs. Nine FAs were identified by DFA as differentiating between milk samples from the 2 years. Of these FAs, 18:1 107 , indicative of Gymnoscopelus nicholsi consumption, was particularly useful in confirming the higher incidence of this species as shown by scat analyses. Also, the higher levels of PUFAs in 1999, par-

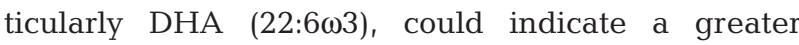
reliance on Protomyctophum tenisoni, which are relatively high in DHA (Lea et al. 2002b), because of the digestibility of their small otoliths.

The significance of such comparisons is undoubtedly influenced by both the number and site of origin of 
potential prey items. Fish of the same species from different localities may vary considerably in FA composition. Fortunately, we could compare milk samples with FA profiles of 8 prey species collected in the foraging zone of fur seals (see Lea et al. 2002b). However, the FA profiles of many prey species, in particular Protomyctophum spp., are yet to be described at Îles Kerguelen, and in many regions of the Southern Ocean.

Previously, significant seasonal shifts in dietary intake of Antarctic fur seals at South Georgia have been identified by Iverson et al. (1997) using FA signature analysis, whilst Brown et al. (1999) could distinguish between the diet of Antarctic fur seals and Southern elephant seals from South Georgia by comparing the FA composition of milk samples to potential prey items. More recently, gray seals from different breeding sites have been differentiated on the basis of milk FA profiles alone, without reference to possible prey items (Walton et al. 2000). Thus, the usefulness of quantitative FA analysis in answering particular questions regarding prey group consumption or inter-site dietary differences is beyond doubt. Although it was possible to statistically discern between milk samples from 2 consecutive years on the basis of milk FA profiles at Îles Kerguelen, isolating those species attributing to the observed difference was less clear. Considerable debate regarding the statistical analysis and interpretation of dietary signature FA analysis has taken place in recent years (Grahl-Nielsen \& Mjaavatten 1995, Iverson et al. 1997, Smith et al. 1997) and although this study provides support for the occurrence of dietary shifts using milk FA analysis, further developments in the analytical tools used to adequately interpret such data are still necessary.

Approximately $94 \%$ of the Antarctic fur seal diet (according to scat analysis) at Îles Kerguelen consists of myctophid fish. The variation in FA composition recorded between species of myctophids is minimal when compared to the larger-scale differences between fish, prey items of other trophic levels and milk profiles. Had milk samples been collected in 1998, a year of higher consumption of fish from other families such as Champsocephalus gunnari, differences in milk compositional profiles may have been more easily attributed to a particular prey family or species.

Interestingly, the proportion of lipid in milk samples also differed between years in addition to the FA profile differences. Percentage lipid was particularly high in year 2000's samples (53\%), which were still within the range of values reported by Arnould \& Boyd (1995) for conspecifics in late lactation at South Georgia and Robinson et al. (in press) at Macquarie Island. Lanternfish of the genus Gymnoscopelus, and Electrona antarctica are particularly rich in lipids, with up to $18 \%$ of wet mass reported for $G$. nicholsi from the Kerguelen region (Lea et al. 2002b). One hypothesis for the observed inter-annual variation in milk lipid content in 1999 and 2000 is the variability in the consumption of Gymnoscopelus spp. in the 2 seasons, which comprised approximately $54 \%$ of the dietary biomass in 1999 and $74 \%$ in 2000 (or 57 and $80 \%$ in terms of energy, respectively). Thus, it would appear that differences in diet between years may also affect the quality of milk stores delivered to pups.

\section{Implications for foraging ecology and oceanic conditions}

On a broad taxonomic scale, the composition of the diet between years was similar as myctophids consistently formed the majority of the diet both in number and in terms of biomass. In all years, Gymnoscopelus piabilis comprised between 27 and $32 \%$ of prey biomass. However, on a finer scale, the composition of prey species was highly variable with the occurrence of icefish Champsocephalus gunnari and Electrona carlsbergi in 1998, a greater proportion of Protomyctophum species in 1999, and perhaps squid as well as a considerably higher proportion of G. nicholsi and myctophids in general in 2000. Changes in oceanographic circulation appear to be responsible for fluctuations in prey abundance (Hunt 1991, McCafferty et al. 1999, Nel et al. 2001), and the position of oceanographic features such as the Antarctic PF may be affected seasonally by weather systems (Priddle et al. 1988). Reid \& Arnould (1996) have suggested that periods of myctophid consumption by female Antarctic fur seals at South Georgia, which usually feed on Antarctic krill, coincide with oceanographic changes bringing concentrations of myctophids, associated with the APF, into the foraging range of the seals. Thus, it is reasonable to suggest that the position of the APF and oceanographic conditions at Kerguelen varied sufficiently within the foraging range of fur seals from 1998 to 2000 to change the species composition of prey available to fur seals.

Guinet et al. (2001) have recently demonstrated that in February 1998 female Antarctic fur seals at Îles Kerguelen tended to forage in the vicinity of the PF in areas of high fish abundance over the continental slope. In our study, 1998 was the year of least myctophid abundance in the diet in comparison to the other 2 years and was also the year that seals dived most deeply on average (Lea et al. 2002). Thus, it would appear that prey availability as measured by the diving behavior of the seals (Boyd et al. 1994, Boyd 1999) and confirmed by dietary analysis varied considerably between years. The higher incidence of scats devoid of otoliths and prey remains in 2000 also tends 
to suggest that seals were foraging farther from the colony in this year. All these factors indicate that possible changes in oceanographic features in the vicinity of the Kerguelen Archipelago from 1998 to 2000 affected the dietary intake and foraging behavior of Antarctic fur seals considerably.

Acknowledgements. This research was generously supported by the Institut Français de Récherche et Technologie Polaires (IFRTP), the Terres Australes et Antarctiques Françaises (TAAF), the Australian Antarctic Scientific Advisory Committee (ASAC) and the Sea World Research and Rescue Foundation Incorporated. All research was conducted under the ethics and scientific approval of the IFRTP. We would like to thank F. Bonadonna, S. Goldsworthy, S. Thalmann, L. Dubro$\mathrm{Ca}, \mathrm{P}$. Bocher and the expeditionists to Kerguelen in 1998 to 2000 who generously provided their assistance in the field. M. Hindell provided many useful comments on an earlier version of the manuscript. B. Mooney and D. Holdsworth managed the CSIRO GC and GC-MS facilities. We also thank G. Duhamel and P. Pruvost for their regular and helpful advice regarding Southern Ocean fishes. Bristol-Myers Squibb kindly provided Clairol Bleaching products.

\section{LITERATURE CITED}

Adams NJ, Klages NT (1987) Seasonal variation in the diet of the king penguin (Aptenodytes patagonicus). J Zool 212: 313-334

Arnould JPY, Boyd IL (1995) Inter- and intra-annual variation in milk composition in Antarctic fur seals (Arctocephalus gazella). Physiol Zool 68:1164-1180

Bester MN, Laycock PA (1985) Cephalopod prey of the subAntarctic fur seal, Arctocephalus tropicalis, at Gough Island. In: Siegfried WR, Condy PR, Laws RM (eds) Antarctic nutrient cycles and food webs. Springer-Verlag, Berlin, p 551-554

Bester MN, Roux JP (1986) The second survey of Antarctic fur seals Arctocephalus gazella on the Courbet Peninsula, Îles Kerguelen. S Afr J Antarct Res 16:33-37

Bligh EG, Dyer W (1959) A rapid method of lipid extraction and purification. Can J Biochem Physiol 37:911-917

Bocher P, Cherel Y, Labat JP, Mayzaud P, Razouls S, Jouventin P (2001) Amphipod-based food web: Themisto gaudichaudii caught in nets and by seabirds in Kerguelen waters, southern Indian Ocean. Mar Ecol Prog Ser 223: 261-276

Bonadonna F, Lea MA, Dehorter O, Guinet C (2001) Foraging ground fidelity and route-choice tactics of a marine predator: the Antarctic fur seal Arctocephalus gazella. Mar Ecol Prog Ser 223:287-297

Bost CA, Georges JY, Guinet C, Cherel Y and 6 others (1997) Foraging habitat and food intake of satellite tracked king penguins during the austral summer at Crozet Archipelago. Mar Ecol Prog Ser 150:21-33

Boyd IL (1999) Foraging and provisioning in Antarctic fur seals: interannual variability in time-energy budgets. Behav Ecol 10:198-208

Brown DJ, Boyd IL, Cripps GC, Butler PJ (1999) Fatty acid signature analysis of the milk of Antarctic fur seals and Southern elephant seals from South Georgia: implications for diet determination. Mar Ecol Prog Ser 187:251-263

Chamaillé-Jammes S, Guinet C, Nicoleau F, Argentier M (2000) A method to assess population changes in king penguins: the use of a Geographical Information System to estimate area-population relationships. Polar Biol 28: 545-549

Clarke A, Clarke MR, Holmes J, Waters TD (1985) Calorific values and elemental analysis of eleven species of oceanic squids (Mollusca: Cephalopoda). J Mar Biol Assoc UK 66: 983-986

Clarke MR (1986) A handbook for the identification of squid beaks. Clarendon Press, Oxford

Claudet J (2001) Dynamique des populations du poisson des glaces (Champsocephalus gunnari) et des espèces accompagnatrices principales dans le nord-est du plateau de Kerguelen. Thèse de Maîtrise, Université Paris VI

Cherel Y, Ridoux V (1992) Prey species and nutritive value of food fed during summer to king penguin Aptenodytes patagonicus chicks at Possession Island, Crozet Archipelago. Ibis 134:118-127

Cherel Y, Ridoux V, Rodhouse PG (1996) Fish and squid in the diet of king penguin chicks, Aptenodytes patagonicus, during winter at sub-antarctic Crozet Islands. Mar Biol 126:559-570

Cherel Y, Guinet C, Tremblay Y (1997) Fish prey of Antarctic fur seals Arctocephalus gazella at Île de Croy, Kerguelen. Polar Biol 17:87-90

Croxall JP, Prince PA, Ricketts C (1985) Relationships between prey life-cycles and the extent, nature and timing of seal and seabird predation in the Scotia Sea. In: Siegfried WR, Condy PR, Laws RM (eds) Antarctic nutrient cycles and food webs. Springer-Verlag, Heidelberg, p 516-533

da Silva J, Neilson JD (1985) Limitations of using otoliths recovered in scats to estimate prey consumption in seals. Can J Fish Aquat Sci 42:1439-1442

Daneri GA (1996) Fish diet of the Antarctic fur seal, Arctocephalus gazella, in summer, at Stranger Point, King George Island, South Shetland Islands. Polar Biol 16:353-355

Daneri GA, Coria NR (1992) The diet of Antarctic fur seals, Arctocephalus gazella, during the summer-autumn period at Mossman Peninsula, Laurie Island (South Orkneys). Polar Biol 11:565-566

Daneri GA, Piatkowski U, Coria NR, Carlini AR (1999) Predation on cephalopods by Antarctic fur seals, Arctocephalus gazella, at 2 localities of the Scotia Arc, Antarctica. Polar Biol 21:59-63

David JHM (1987) Diet of the South African fur seal (1974-1985) and an assessment of competition with fisheries in southern Africa. In: Payne AIL, Gulland JA, Brink $\mathrm{KH}$ (eds) The Benguela and comparable ecosystems. S Afr J Mar Sci 5:693-713

Dellinger T, Trillmich F (1988) Estimating diet composition from scat analysis in otariid seals (Otariidae): is it reliable? Can J Zool 66:1865-1870

Doidge DW, McCann TS, Croxall JP (1986) Attendance behaviour of Antarctic fur seals. In: Gentry RL, Kooyman GL (eds) Fur seals: maternal strategies on land and at sea. Princeton University Press, Princeton, NJ, p 102-114

Duhamel G (1991) The biological and demographic peculiarities of the icefish Champsocephalus gunnari Lönnberg, 1905 from the Kerguelen Plateau. In: Di Prisco G, Maresca B, Tota B (eds) Biology of Antarctic fish. Springer-Verlag, Berlin, p 40-53

Duhamel G, Hureau JC (1985) The role of zooplankton in the diets of certain sub-antarctic marine fish. In: Siegfried WR, Condy PR, Laws RM (eds) Antarctic nutrient cycles and food webs. Springer-Verlag, Berlin, p 422-429

Duhamel G, Koubbi P, Ravier C (2000) Day and night mesopelagic fish assemblages off the Kerguelen Islands (Southern Ocean). Polar Biol 23:106-112 
Fea N, Harcourt RG (1997) Assessing the use of faecal and regurgitate analysis as a means of determining the diet of New Zealand fur seals. In: Hindell M, Kemper C (eds) Marine mammal research in the southern hemisphere, Vol 1: Status, ecology and medicine. Surrey Beatty and Sons, Chipping Norton, p 143-150

Ferreira SM, Bester MN (1999) Chemical immobilsation, physical restraint, and stomach lavaging of fur seals (ArCtocephalus spp.) at Marion Island. S Afr J Wildl Res 29: $55-61$

Gales NJ, Cheal AJ (1992) Estimating diet composition of the Australian sea-lion (Neophoca cinerea) from scat analysis: an unreliable technique. Wildl Res 19:447-456

Gales R, Pemberton D, Lu CC, Clarke MR (1993) Cephalopod diet of the Australian fur seal: variation due to location, season and sample type. Aust J Mar Freshw Res 44: $657-671$

Goldsworthy SD (1992) Maternal care in 3 species of southern fur seal (Arctocephalus spp.). PhD thesis, Monash University, Melbourne

Goldsworthy SD, Hindell MA, Crowley HM (1997) Diet and diving behaviour of sympatric fur seals Arctocephalus gazella and A. tropicalis at Macquarie Island. In: Hindell M, Kemper C (eds) Marine mammal research in the southern hemisphere, Vol 1: Status, ecology and medicine. Surrey Beatty and Sons, Chipping Norton, p 151-163

González AF, Rodhouse PG (1998) Fishery biology of the 7 star flying squid Martialia hyadesi at South Georgia during winter. Polar Biol 19:231-236

Grahl-Nielsen O, Mjaavatten O (1995) Marine mammalian fatty acids: a source of information. In: Blix AS, Walloe L, Ulltang $O$ (eds) Whales, seals, fish and man. Elsevier Science Publishers, Amsterdam, p 141-152

Green K, Williams R, Handasyde KA, Burton HR, Shaughnessy PD (1990) Interspecific and intraspecific differences in the diets of fur seals, Arctocephalus species (Pinnipedia: Otariidae), at Macquarie Island. Aust Mammal 13: 193-200

Green K, Williams R, Burton HR (1997) Foraging ecology of Antarctic fur seals Arctocephalus gazella Peters around Heard Island. In: Hindell M, Kemper C (eds) Marine mammal research in the southern hemisphere, Vol 1: Status, ecology and medicine. Surrey Beatty \& Sons, Chipping Norton, p 105-113

Guinet C, Cherel Y, Ridoux V, Jouventin P (1996) Consumption of marine resources by seabirds and seals in Crozet and Kerguelen waters: changes in relation to consumer biomass 1962-85. Antarct Sci 8:23-30

Guinet C, Dubroca L, Lea MA, Goldsworthy SD, Cherel Y, Duhamel G, Bonadonna F, Donnay JP (2001) Spatial distribution of foraging in female Antarctic fur seals Arctocephalus gazella in relation to oceanographic variables: a scale dependent approach using geographic information systems. Mar Ecol Prog Ser 219:251-264

Helm RC (1984) Rate of digestion in 3 species of pinnipeds. Can J Zool 62:1751-1756

Hempel G (1985) Antarctic marine food webs. In: Siegfried WR, Condy PR, Laws RM (eds) Antarctic nutrient cycles and food webs. Springer-Verlag, Heidelberg, p 266-270

Hulley PA (1990) Family Myctophidae lanternfishes. In: Gon O, Heemstra PC (eds) Fishes of the Southern Ocean. JCB Institute of Ichthyology, Grahamstown, p 146-178

Hunt BPV, Pakhomov EA, McQuaid CD (2001) Short-term variation and long-term changes in the oceanographic environment and zooplankton community in the vicinity of a sub-Antarctic archipelago. Mar Biol 138:369-381

Hunt GL Jr (1991) Occurrence of polar seabirds at sea in relation to prey concentrations and oceanographic factors Polar Res 10:553-559

Iverson SJ (1993) Milk secretion in marine mammals in relation to foraging: can milk fatty acids predict diet? Symp Zool Soc Lond 66:263-291

Iverson SJ, Arnould JPY, Boyd IL (1997) Milk fatty acid signatures indicate both major and minor shifts in the diet of lactating Antarctic fur seals. Can J Zool 75:188-197

Jackson G (1995) The use of beaks as tools for biomass estimation in the deepwater squid Moroteuthis ingens (Cephalopoda: Onychoteuthidae) in New Zealand waters. Polar Biol 15:9-14

Jobling M, Breiby A (1986) The use and abuse of fish otoliths in studies of feeding habits of marine piscivores. Sarsia 71: 265-274

Jouventin P, Stahl JC, Weimerskirch H (1982) La recolonisation des îles Crozet par les otaries (Arctocephalus tropicalis et A. gazella). Mammalia 46:505-514

Kirkman SP, Wilson W, Klages NTW, Bester MN, Isaksen K (2000) Diet and estimated food consumption of Antarctic fur seals at Bouvetøya during summer. Polar Biol 23: $745-752$

Kirsch PE, Iverson SJ, Bowen WD (2000) Effect of low-fat diet on body composition and blubber fatty acids of captive juvenile harp seals (Phoca groenlandica). Physiol Biochem Zool 73:45-59

Klages NT (1996) Cephalopods as prey. II. Seals. Philos Trans R Soc Lond B 351:1045-1052

Klages NTW, Bester MN (1998) Fish prey of fur seals Arctocephalus spp. at subantarctic Marion Island. Mar Biol 131: 559-566

Klyausov AV (1990) Position of the South Polar Front near Kerguelen and Heard Islands in the autumn of 1987. Oceanology 30:142-148

Kozlov AN (1995) A review of the trophic role of mesopelagic fish of the family Myctophidae in the Southern Ocean ecosystem. CCAMLR Sci 2:71-77

Kozlov AN, Tarverdiyeva MI (1989) Feeding of different species of Myctophidae in different parts of the Southern Ocean. J Ichthyol 29:160-167

Kubodera T, Piatowski U, Okutani T, Clarke MR (1998) Taxonomy and zoogeography of the family Onychoteuthidae (Cephalopoda: Oegopsida). In: Voss NA, Vecchione M, Toll RB, Sweeney MJ (eds) Systematics and biogeography of cephalopods, Vol 2. Smithsonian Institution Press, Washington, DC, p 277-291

Lake S (1997) Analysis of the diet of New Zealand fur seals Arctocephalus forsteri in Tasmania. In: Hindell M, Kemper $\mathrm{C}$ (eds) Marine mammal research in the southern hemisphere, Vol 1: Status, ecology and medicine. Surrey Beatty and Sons, Chipping Norton, p 125-129

Lea MA, Hindell M, Guinet C, Goldsworthy SD (2002a) Variability in the diving activity of Antarctic fur seals, Arctocephalus gazella, at Îles Kerguelen. Polar Biol 25:269-279

Lea MA, Nichols PD, Wilson G (2002b) Fatty acid composition of lipid-rich myctophids and mackerel icefish - Southern Ocean food-web implications. Polar Biol 25:843-854

Lutjeharms JRE, Walters NM, Allanson BR (1985) Oceanic frontal systems and biological enhancement. In: Siegfried WR, Condy PR, Laws RM (eds) Antarctic nutrient cycles and food webs. Springer-Verlag, Heidelberg, p 11-21

McCafferty DJ, Boyd IL, Walker TR, Taylor RI (1999) Can marine mammals be used to monitor oceanographic conditions? Mar Biol 134:387-395

Moore GJ, Robertson G, Wienecke B (1998) Food requirements of breeding king penguins at Heard Island and potential overlap with commercial fisheries. Polar Biol 20:293-302 
Moore JK, Abbott MR, Richman JG (1999) Location and dynamics of the Antarctic Polar Front from satellite sea surface temperature data. J Geophys Res 104:3059-3073

Nel DC, Lutjeharms JRE, Pakhomov EA, Ansorge IJ, Ryan PG, Klages NTW (2001) Exploitation of mesoscale oceanographic features by grey-headed albatross Thalassarche chrysostoma in the southern Indian Ocean. Mar Ecol Prog Ser 217:15-26

North AW (1996) Fish in the diet of Antarctic fur seals (Arctocephalus gazella) at South Georgia during winter and spring. Antarct Sci 8:155-160

North AW, Croxall JP, Doidge DW (1983) Fish prey of the Antarctic fur seal Arctocephalus gazella at South Georgia. Br Antarctic Surv Bull 61:27-37

Oftedal OT (1984) Milk composition, milk yield and energy output at peak lactation: a comparative review. Symp Zool Soc Lond 51:33-85

Olsson O, North AW (1997) Diet of the King penguin Aptenodytes patagonicus during 3 summers at South Georgia. Ibis 139:504-512

Pakhomov EA, Froneman PW (2000) Composition and spatial variability of macroplankton and micronekton within the Antarctic Polar Frontal Zone in the Indian Ocean during the austral autumn 1997. Polar Biol 23:410-419

Pakhomov EA, Perissinotto R, McQuaid CD (1994) Comparative structure of the macro-zooplankton/micronekton communities of the Subtropical and Antarctic Polar Fronts. Mar Ecol Prog Ser 111:155-169

Park YH, Gambéroni L (1995) Large-scale circulation and its variability in the south Indian Ocean from TOPEX/POSEIDON altimetry. J Geophys Res 100:24 911-24 929

Park YH, Gambéroni L (1997) Cross-frontal exchange of Antarctic Intermediate Water and Antarctic Bottom Water in the Crozet Basin. Deep-Sea Res II 44:963-986

Park YH, Gambéroni L, Charriaud E (1993) Frontal structure, water masses and circulation in the Crozet Basin. J Geophys Res 98:12 361-12 385

Phillips KL, Jackson GD, Nichols PD (2001) Predation on myctophids by the squid Moroteuthis ingens around Macquarie and Heard Islands: stomach contents and fatty acid analyses. Mar Ecol Prog Ser 215:179-189

Phleger CF, Nichols PD, Virtue P (1998) Lipids and trophodynamics of Antarctic zooplankton. Comp Biochem Physiol B 120:311-323

Phleger CF, Nelson MM, Mooney BD, Nichols PD (1999) Wax esters versus triacylglycerols in myctophid fishes from the Southern Ocean. Antarct Sci 11:437-445

Pierce GJ, Boyle PR (1991) A review of methods for diet analysis in piscivorous marine mammals. In: Barnes M (ed) Oceanography and marine biology - an annual review, Vol 29. Aberdeen University Press, Aberdeen, p 409-486

Priddle J, Croxall JP, Everson I, Heywood RB, Murphy EJ, Prince PA, Sear CB (1988) Large-scale fluctuations in distribution and abundance of krill-a discussion of possible causes. In: Sahrhage D (ed) Antarctic ocean and resources variability. Springer-Verlag, Berlin, p 169-182

Raclot T, Groscolas R, Cherel Y (1998) Fatty acid evidence for the importance of myctophid fishes in the diet of king penguins, Aptenodytes patagonicus. Mar Biol 132:523-533

Reid K (1995) The diet of Antarctic fur seals (Arctocephalus gazella Peters 1875) during winter at South Georgia. Antarct Sci 7:241-249

Reid K (1996) A guide to the use of otoliths in the study of

Editorial responsibility: Otto Kinne (Editor),

Oldendorf/Luhe, Germany predators at South Georgia. British Antarctic Survey, Cambridge

Reid K, Arnould JPY (1996) The diet of Antarctic fur seals Arctocephalus gazella during the breeding season at South Georgia. Polar Biol 16:105-114

Reinhardt SB, van Vleet ES (1986) Lipid composition of twenty-two species of Antarctic midwater zooplankton and fish. Mar Biol 91:149-159

Robinson SA, Goldsworthy SD, van den Hoff J, Hindell MA (in press) The foraging ecology of 2 sympatric fur seal species at Macquarie Island, Arctocephalus gazella and A. tropicalis, during the austral summer. J Mar Freshw Res

Rodhouse PG, White MG (1995) Cephalopods occupy the ecological niche of epipelagic fish in the Antarctic Polar Frontal Zone. Biol Bull (Woods Hole) 189:77-80

Rodhouse PG, Prince PA, Clarke MR, Murray AWA (1990) Cephalopod prey of the grey-headed albatross Diomedea chrysostoma. Mar Biol 104:353-362

Sabourenkov E (1991) Myctophids in the diet of Antarctic predators. Selected Scientific Papers, 1991 (SC-CAMLRSSP/8). CCAMLR, Hobart, p 335-357

Schnack SB (1985) Feeding by Euphausia superba and copepod species in response to varying concentrations. In: Siegfried WR, Condy PR, Laws RM (eds) Antarctic nutrient cycles and food webs. Springer-Verlag, Heidelberg, p 311-323

Seo HS, Endo Y, Fujimoto K, Watanabe H, Kawaguchi K (1996) Characterization of lipids in myctophid fish in the subarctic and tropical Pacific Ocean. Fish Sci 62:447-453

Smith SJ, Iverson SJ, Bowen WD (1997) Fatty acid signatures and classification trees: new tools for investigating the foraging ecology of seals. Can J Zool 54:1377-1386

Staniland IJ (2002) Investigating the biases in the use of hard prey remains to identify diet composition using Antarctic fur seals (Arctocephalus gazella) in captive feeding trials. Mar Mamm Sci 18:223-243

Tierney M, Hindell M, Goldsworthy SD (2002) Energy content of mesopelagic fish from Macquarie Island. Antarct Sci 14: $225-230$

Volkman JK, Nichols PD (1991) Applications of thin-layer chromatography-flame ionization detection to the analysis of lipids and pollutants in marine environmental samples. J Planar Chromatogr Mod TLC 4:19-26

Walton MJ, Henderson RJ, Pomeroy PP (2000) Use of blubber fatty acid profiles to distinguish dietary differences between grey seals Halichoerus grypus from 2 UK breeding colonies. Mar Ecol Prog Ser 193:201-208

White WB, Peterson RG (1996) An Antarctic circumpolar wave in surface pressure, wind, temperature and sea-ice extent. Nature 380:699-702

Williams D, McEldowney A (1990) A guide to the fish otoliths off the Australian Antarctic Territory and Heard and Macquarie Islands. Australian Antarctic Division, Hobart

Wormuth JH (1998) Workshop deliberations on the Ommastrephidae: a brief history of their systematics and a review of the systematics, distribution and biology of the Genera Martialia Rochebrune and Mabille, 1889, Todaropsis Girard, 1890, Dosidicus Steenstrup, 1857, Hyaloteuthis Gray, 1849, and Eucleoteuthis Berry, 1916. In: Voss NA, Vecchione M, Toll RB, Sweeney MJ (eds) Systematics and biogeography of cephalopods, Vol 2. Smithsonian Institution Press, Washington, DC, p 373-383

Zar JH (1996) Biostatistical analysis, 3rd edn. Prentice-Hall, New York

Submitted: April 22, 2002; Accepted: September 17, 2002

Proofs received from author(s): November 18, 2002 